\title{
The Effect of Education Level and Gender on Students' Metacognitive Skills in Malang, Indonesia
}

\author{
Bea Hana Siswati \\ Postgraduate student \\ State University of Malang, Indonesia \\ Aloysius Duran Corebima \\ Faculty of Mathematics \& Natural Science \\ State University of Malang, Indonesia
}

\begin{abstract}
The students' thinking ability will develop with age. Educators are expected to know the development of the students' thinking ability, so that the empowerment of their thinking abilities, including metacognitive skills, can be done optimally. Gender is believed to be associated with the development of a person's thinking ability. This quasi experimental research aimed at investigating the effect of level of education and gender on students' metacognitive skills. The population of this research was the students of junior high schools and senior high schools in malang in 2015/2016 academic year. The school samples used in this research were junior high school muhammadiyah 1 and senior high school muhammadiyah 1 malang. The metacognitive skills were measured by essay test, and assessed by using the rubric of metacognitive skills. The results of the data analysis showed that the education level had an effect on students' metacognitive skill, but gender as well as the interaction between education level and gender did not have an effect on students' metacognitive skill. It is recommended to conduct further research related to the effect of education level on metacognitive skill using a bigger number of samples and even involving the samples studying at elementary school level.
\end{abstract}

Keywords: concept gaining, education level, gender, metacognitive skills

\section{INTRODUCTION}

Metacognition is one of the skills required to be empowered in the education world. Metacognition is known as thinking how to think (Flavel, 1979). Metacognitive skill includes the skills of planning, evaluating and monitoring the learning (Vrieling et al., 2012). Metacognition helps a person to understand something and to control his cognitive ability. Therefore, student metacognitive skills should be trained as early as possible. Flavel (1979) stated that metacognition referred to a person's knowledge of how to regulate his cognitive abilities and activities in learning. Kramarski and Mizrachi (2004) stated that metacognitive ability could be observed when the students were aware of their cognitive abilities.

The importance of the students' metacognitive skill empowerment leads to the goals of education, which is, improving the quality of education. Metacognitive skills can also be used by students to solve problems during the learning process. Moreover, it is also possible that with good metacognitive skills students will be able to compete in a globalization world in the 21st century nowadays. According to Flavel (1979), a person's ability to monitor his various cognitive activities is performed through action and interaction among four components, namely; a) metacognitive knowledge, b) metacognitive experiences, c) goals or tasks, and d) actions or strategies. 
According to Pintrich (2002), metacognitive skills cannot be considered as lessons to be taught, but it must be given to the students by integrating it with particular school subjects. Furthermore, the educators should know how and where they should teach/empower the students' metacognitive skills during the teaching learning process. Therefore, educators should have a plan to empower students' metacognitive skills.

The empowerment of students' metacognitive skills can be done in several ways. Educators usually empower the students' metacognitive skills by applying learning models/ strategies. One of the learning models that can be used to empower students' metacognitive skills is Think Pair Share (TPS). The TPS learning model is believed to be able to empower students' metacognitive skills. Corebima (2008) stated that cooperative learning was more potential in empowering students' thinking skills and concept gaining. Some researches have proven that pure TPS or TPS integrated with other learning models was able to give good effect on the increase of students' metacognitive skills. The researches related to TPS learning model were conducted by Jamaluddin (2009), Amnah (2011), Sarwinda (2011), Haerullah (2012), and Ekoningtyas (2013).

The students' thinking ability should be empowered as early as possible. The thinking ability which is trained from childhood will enable a person to face the problems faced. According to Ruggiero in Johnson (2007), thinking is all mental activities that helps to formulate or to solve problems, to make decisions, to fulfill the desire to understand, and to search for answers and meaning.

According to cognitive psychologist, Piaget, cognitive development of a person is a genetic process based on the biological mechanisms of the nervous system development. Piaget also explains that cognitive development cannot be defined quantitatively, but it is defined qualitatively.

Students also need to understand the stages of cognitive development. How is the thinking development of junior high school and senior high school students? Piaget explains that children, whose ages range 11-18 years old, are at the formal operational stage. The characteristics of this stage are that a person can work effectively and systematically, analyze in combinations, think proportionately, and generalize the available information.

Educators are expected to be able to understand the stages of cognitive development of the students, so that educators can design and implement a learning process in accordance with the stages of the cognitive development. Holland, Joyner \& Kurtz-Costes (1997) stated that essentially a child has had the basic knowledge related to metacognition and metamemory, but as they get older, they would learn to manage their cognitive resources more strategically and to develop better ways to use and to monitor their strategy. Flavell (1992) stated that the concept of metacognition was included in the development stages of formal operational thinking. Metacognition awareness of a person may start to develop at the age of 4-6 years (Kuhn, 1999). Further development of metacognitive knowledge and skills occurs in the subsequent years (Alexander et al., 1995) and (Kuhn, 1999). There has not been any quantitative information on the development levels of metacognitive skills in different levels of education, for example, between junior high school and senior high school level of education.

The research results related to the effect of levels of education on metacognitive skills are expected to be the foundation by the educator in empowering the students' thinking skills, particularly their metacognitive skills. 
In addition to learning models/strategies, in the previous researches, gender is also often associated with the empowerment of thinking ability, particularly metacognitive skills. The research on cognitive abilities related to gender differences is based on memory, language skills, and ability to solve math problems. Males have a good capability in visio-spatial processes, while females are better in verbal ability Niemivirta (1997). Ciascai et al. (2011) explained that a lot of research have been conducted to investigate the metacognitive skills between male and female students. Some researches show that there is a significant difference, but some others show that there is not a significant difference. Thus, in this case the effect of gender on metacognitive skills in TPS learning needs to be revealed.

The results of this research will be able to broaden the educators' knowledge in empowering the students' metacognitive skill, whether they need yet to pay attention to the aspects of gender or not. Therefore the research is conducted in order to investigate the effect of education levels and gender on students' metacognitive skill especially in TPS learning.

\section{METHOD}

This is a quasi experimental research using Pretest-Posttest Nonequivalent Control Group Design, conducted for one semester in the first semester of the 2015/2016 academic year. The independent variables in this research were levels of education (junior and senior high school) and gender (male and female), while the dependent variable was the students' metacognitive skills. The population of this research was all the students of junior and senior high schools in Malang. The samples of this research were the students of class VII and class VIII of Junior High School Muhammadiyah 1 Malang and the students of class X and XI of Senior High School Muhammadiyah 1 Malang. The learning model used in this research was Think Pair Share (TPS). The metacognitive skill was measured by using a test integrated with an essay test supported by a specific rubric (Corebima, 2009). The test instrument was first tested for the validity and reliability. The data were collected during the pretest and posttest. Hypothesis testing used two way Ancova with a significance level of $0.05(\mathrm{P}<0.05)$. Before the Ancova test was performed, prerequisite tests, namely the normality test of the data was conducted by Kormogolov-Smirnov test and the homogeneity test of the data was conducted by Levene test. The data were analyzed by using SPSS version 16.00 for Windows.

\section{RESULT}

The result summary of Ancova related to the effect of levels of education and gender on students' metacognitive skills in Malang are shown in Table 1. 
Table 1. The Result Summary of Ancova related to the Effect of Levels of Education and Gender on Students' metacognitive Skill

\begin{tabular}{|c|c|c|c|c|c|}
\hline \multicolumn{6}{|c|}{ Tests of Between-Subjects Effects } \\
\hline \multicolumn{2}{|c|}{ Dependent Variable:YMetaSkill } & \multirow[b]{2}{*}{ df } & \multirow[b]{2}{*}{$\begin{array}{l}\text { Mean } \\
\text { Square }\end{array}$} & \multirow[b]{2}{*}{$\mathbf{F}$} & \multirow[b]{2}{*}{ Sig. } \\
\hline Source & $\begin{array}{c}\text { Type III Sum of } \\
\text { Squares }\end{array}$ & & & & \\
\hline Corrected Model & $2715.595^{\mathrm{a}}$ & 4 & 678.899 & 7.896 & .000 \\
\hline Intercept & 12270.285 & 1 & 12270.285 & 142.708 & .000 \\
\hline XmetaSkill & 2032.601 & 1 & 2032.601 & 23.640 & .000 \\
\hline Levels of education & 534.667 & 1 & 534.667 & 6.218 & .014 \\
\hline Gender & 43.564 & 1 & 43.564 & .507 & .478 \\
\hline $\begin{array}{l}\text { Levels of Education * } \\
\text { Gender }\end{array}$ & 7.958 & 1 & 7.958 & .093 & .762 \\
\hline Error & 9114.045 & $\begin{array}{r}10 \\
6\end{array}$ & 85.982 & & \\
\hline Total & 136165.000 & $\begin{array}{r}11 \\
1\end{array}$ & & & \\
\hline Corrected Total & 11829.640 & $\begin{array}{r}11 \\
0 \\
\end{array}$ & & & \\
\hline \multicolumn{3}{|c|}{ a. R Squared $=, 230$ (Adjusted R Squared $=, 200$ ) } & & & \\
\hline
\end{tabular}

The results of the data analysis related to the effect of education level on metacognitive skills showed that the significant p-level was 0.014 , which was smaller than the alpha of 0.05 (p $<0.05)$. This means that $\mathrm{HO}$ was rejected, and the alternative hypothesis was accepted. It means that there was a difference in metacognitive skills between junior high school students and senior high school students. The metacognitive skill of senior high school students was 14.7 $1 \%$ higher than that of the junior high school students.

The results of the data analysis related to the effect of gender on metacognitive skills showed that the significant $\mathrm{p}$-level was 0,478 , which was greater than the alpha of $0.05(\mathrm{p}>0.05)$. This means that $\mathrm{HO}$ was accepted, and the alternative hypothesis was rejected. It means that there was not any difference in metacognitive skills between male and female students. Although it was proven that there was not any difference in metacognitive skills between male and female students, the metacognitive skill of the male students was 3.98\% higher than that of the female students.

The results of the analysis related to the effect of the interaction between education level and gender on metacognitive skill showed that the significance p-level was 0.762 , which was greater than the alpha of 0.05 ( $p>0.05$ ). It means that the $\mathrm{H} 0$ was accepted, and the alternative hypothesis was rejected. It indicates that the interaction between education level and gender did not have an effect on the students' metacognitive skill.

\section{DISCUSSION}

Based on the results of the Ancova test, it can be concluded that the education level has an effect on students' metacognitive skills. Metacognitive skills grow and develop with age. In general, metacognitive skills begin to develop at the age of about 5 to 7 years (Woolfolk, 2004). Lambertus (2009) stated that when a person had the opportunity to use his/her higher order 
thinking in each class, including at any level, he/she will be accustomed to distinguish between the truth and the untruth, the fact and the opinion, the knowledge and the belief. Furthermore, it was explained that higher order thinking would help students to be accustomed to think deeply, to live with an intelligent, balanced, and accountable approach. Piaget states that there are four factors affecting a person's intellectual development, namely: experience, maturity, social transmission and equilibration or internal equilibrium. The interaction of these four factors becomes the basis for the intellectual development or construction of a person's mental structure.

The results of the research analysis cannot be separated from the learning models used during the learning process. The TPS learning model provides an opportunity for the students to work independently and collaboratively with others (Lie, 2008). By training themselves to think and to solve problems, the students' metacognitive skills can be trained optimally. Kramarski and Mevarech (2003) found that different learning models might give different effects on students' metacognition. In his research, metacognitive approach was integrated with a variety of learning models, such as metacognitive approach integrated with cooperative learning and metacognitive approach integrated with individual learning. The results showed that the reasoning ability of the students who learned using metacognitive approach integrated with cooperative learning achieved better results.

The results of the analysis showed that there was not any difference in metacognitive skills between male and female students. This is in line with the research conducted by Kamid (2013) explaining that there was not any difference in metacognition ability between male and female students when completing a task. Furthermore, it was explained that male and female students had equal metacognitive skills in terms of understanding, planning, implementing, and doing a reflection of their work (reflection). The same results were also revealed by Niemivirta (1997), Carr and Jessup (1997), Bidjerano (2005), Memnun and Akkaya (2009), and Ozsoy and Gunindi (2011).

This is in contrast with the results of the research conducted by Ogus and Ataseven (2016) and Ciscai, Liliana, and Lavinia (2011) explaining that there was a significant difference in metacognitive skills between male and female students. In general, both males and females have used their metacognitive skills, although the dimensions of the metacognitive skill used were different. The differences in the results of the research might have occurred because of the different learning models used which led to different results. In addition, the differences in culture and location of the researches might have been the factors causing the different results of the researches.

There is another analysis result yet. The results of the analysis of two way Ancova showed that the interaction between level of education and gender did not have an effect of students' metacognitive skills.

\section{Conclusion}

\section{CONCLUSION \& SUGGESTION}

Based on the research result and discussion, it can be concluded that:

1. Levels of education had an effect on students' metacognitive skills in TPS learning model. The metacognitive skills of senior high school students were $14.71 \%$ higher than those of the junior high school students.

2. Gender did not have an effect on students' metacognitive skills in TPS learning model. 
3. The interaction between level of education and gender did not have an effect on students' metacognitive skills in TPS learning model.

\section{Suggestion}

Based on the results of this research, it is suggested that further research related to the effect of level of education on metacognitive skill with the samples of elementary school need to be conducted. In this case, the effect of gender on metacognitive skills in the implementation of the other learning models (other than TPS) which has the potential to empower students' metacognitive skills needs to be revealed. Through a similar research, more extensive information related to the empowerment of students' metacognition in various levels of education, between genders, and even among learning models, etc can be obtained.

\section{References}

Alexander, J. M., Carr, M., \& Schwanenflugel, P. J. (1995). Development of metacognition in gifted children: directions for future research, Developmental Review, 15, 1-37.

Amnah, S. (2011). Pembelajaran Think-Pair-Share, Keterampilan Metakognitif, Dan Hasil Belajar Kognitif Siswa SMA [Think-Pair-Share Learning, Metacognitive Skills, and Cognitive Learning Outcomes of Senior High School Students], Jurnal Ilmu Pendidikan, 17(6), 489-493.

Bidjerano, T. (2005). Gender differences in self-regulated learning, retrieved 20 August, 2016 from http://eric.ed.gov/?id=ED490777.

Carr, M., \& Jessup, D. L. (1997). Gender differences in first-grade mathematics strategy use: Social and metacognitive influences, Journal of Educational Psychology, 89(2), 318-328.

Ciascai, Liliana, \& Lavina, H. (2011). Gender differences in metacognitive skills. A study of the $8^{\text {th }}$ grade pupils in Romania, Procedia - Social and Behavioral Sciences, 29, 396 - 401.

Corebima, A.D. (2008). Review on: Learning Strategies Having Bigger Potency to Empower Thinking Skill And Concept Gaining of Lower Academic Students, Redesigning Pedagogy International Conference, December 2008.

Corebima, A.D. (2009). Metacognitive Skill Measurement Integrated in Achievement Test, Retrieved 19 May, 2016 from

http://www.recsam.edu.my/cosmed/cosmed09/AbstractsFullPapers2009/Abstract/Science\%20Parallel\%20PD F/Full\%20Paper/01.pdf.

Ekoningtyas, M. (2013). Pengaruh Pembelajaran Think-Pair-Share dipadu Pola Pemberdayaan Berpikir melalui Pertanyaan terhadap Keterampilan Metakognitif, Berpikir Kreatif, Pemahaman Konsep IPA dan Retensinya serta Sikap Sosial Siswa [The Effect of Think-Pair-Share Learning integrated with Thinking Empowerment by Questioning Learning on the students' Metacognitive Skills, Creative Thinking, Science Concept Gaining and retention, Social Attitudes], Jurnal Pendidikan Sains, 1(4), 332-342.

Flavell, J. H. (1979). Metacognition and Cognitive Monitoring, A New Area of Cognitive-Developmental Inquiry, in Nelson, T. O. (Ed), 1992, Metacognition, Allyn and Bacon, Boston.

Flavell, J. H. (1992). Perspectives on perspective taking. In H. Beilin, \& P. Pufall (Eds.), Piaget's theory: prospects and possibilities. Hillsdale, NJ: Erlbaum.

Gurian, M., Kathy, S., Particia, H. \& Terry, T. (2011). Boy and Girls Learn Differenty: A Guide for Teachers and Parent Rev. 10th anniversary ed. Jossey-Bass A wiley Imprint, retrieved 01 June, 2016 from www.josseybass.com.

Haerullah, A.H. (2012). Pengembangan Perangkat Pembelajaran Pemberdayaan Berpikir Melalui Pertanyaan (PBMP) dan Think Pair Share (TPS) serta Pengaruh Penerapannya terhadap Metakognisi, Berpikir Kritis, dan Sikap Sosial Siswa SD Multietnis di Kota Ternate [Developing Learning Materials of Thinking Empowerment by Questioning (TEQ) and Think Pair Share (TPS) and the Effect of Its' Implementation on Metacognition, critical 
Thinking, and social Attitudes of multiethnic elementary School Students in Ternate], Unpublished doctoral dissertation., State University of Malang, Malang, Indonesia.

Holland Joyner, M. \& Kurtz-Costes, B. (1997). Metamemory development. In N. Cowan \& C. Hulme (Eds.), The development of memory in childhood, East Sussex: Psychology Press.

Inhelder, B., \& Piaget, J. (1958). The growth of logical thinking from childhood to adolescence, London: Routledge \& Kegan.

Jamaluddin. (2009). Pengaruh Pembelajaran Berpikir Melalui Pertanyaan Dipadukan Strategi Kooperatif dan Kemampuan Akademik terhadap Keterampilan Metakognitif, Berpikir Kreatif, Pemahaman Konsep IPA Biologi, dan Retensi Siswa SD di Mataram [The Effect of Thinking Empowerment by Questioning integrated with cooperative Strategy and academic Ability on metacognitive Skills, creative Thinking, Biology Science Concept Gaining, and Retention of elementary School Students in Mataram], Unpublished doctoral dissertation, State University of Malang, Malang, Indonesia.

Kamid. (2013). Metakognisi Siswa dalam Menyelesaikan Soal Matematika (Studi Kasus pada Siswa SMP berdasarkan Gender] [Students' Metacognition in Solving Mathematical Problems (Case Study on Junior High School Students based on Gender)], Edumatica, 3(1), 64-72.

Kramarski, B. \& Mevarech, Z. R. (2003). Enhancing mathematical reasoning in the classroom: Effects of cooperative learning and metacognitive training. American Educational Research Journal, 40(1), 281-310.

Kramarski, B. \& Mizrachi, N. (2004). Enhancing Mathematical Literacy With The Use Of Metacognitive Guidance in Forum Discussion, Proceedings of the 28th Conference of The International Group for The Psychology of Mathematics Education, 3, 169 - 176.

Kuhn, D. (1999). Metacognitive development. In L. Balter, \& C. S. Tamis-LeMonda (Eds.), Child psychology. A handbook of contemporary issues, Philadelphia: Psychology Press.

Lambertus. (2009). Pentingnya Melatih Keterampilan Berpikir Kritis dalam Pembelajaran Matematika di SD [The Importance of Critical Thinking Skill Training in Mathematics Learning in Elementary School], Forum Kependidikan, 28(2), 136-142.

Memnun, D. S. \& Akkaya, R. (2009). The levels of metacognitive awareness of primary teacher trainees. ProcediaSocial and Behavioral Sciences, 1(1), 1919-1923.

Niemivirta, M. (1997). Gender differences in motivational-cognitive patterns of selfregulated learning, Paper presented at the annual meeting of the American Educational Research Association, Chicago, IL, Retrieved 01

August, 2016 from http://files.eric.ed.gov/fulltext/ED410478.pdf.

Oguz, A., \& Ataseven, N. (2016). The Relationship Between Metacognitive Skills and Motivation of University Students, Educational Process: International Journal, 5(1), 54-64.

Ozsoy, G. \& Gunindi, Y. (2011). Prospective preschool teachers' metacognitive awareness, Elementary Education Online, 10(2), 430-440.

Pintrich, P. R. (2002) The role of metacognitive knowledge in learning, teaching, and assessing, Theory into Practice, 41(4), 219-225.

Sarwinda, W. (2011). Pengaruh Strategi Pembelajaran Think Pair Share dipadu Reciprocal Teaching dan Kemampuan Akademik yang Berbeda terhadap Hasil Belajar Kognitif dan Keterampilan Berpikir Kreatif pada Siswa SMA Negeri 1 Batu dan SMA Negeri 1 Grati [The Effect of Think Pair Share Learning Strategy integrated with reciprocal Teaching and different academic Ability on cognitive Learning Results and creative Thinking Skills of State Senior High School Students 1 Batu and State Senior High School 1 Grati], Unpublished master's thesis, State University of Malang, Malang, Indonesia.

Vrieling, E., Bastiaens, T., \& Stijnen, S. (2012). Effects of increased self-regulated learning opportunities on student teachers' motivation and use of metacognitive skills, Australian Journal of Teacher Education, 37(8), 101-117. 